\title{
Litter dwelling mygalomorph spiders (Araneae: Microstigmatidae, Nemesiidae) from Araucaria forests in southern Brazil, with the description of five new species
}

\author{
Rafael P. Indicatti ${ }^{1}$; Sylvia M. Lucas ${ }^{1}$; Ricardo Ott ${ }^{2} \&$ Antonio D. Brescovit ${ }^{1}$ \\ ${ }^{1}$ Laboratório de Artrópodes, Instituto Butantan. Avenida Vital Brazil 1500, 05503-900 São Paulo, São Paulo, Brasil. \\ E-mail: indicatti@butantan.gov.br; sylvialucas@butantan.gov.br; anyphaenidae@butantan.gov.br \\ ${ }^{2}$ Museu de Ciências Naturais, Fundação Zoobotânica do Rio Grande do Sul. Rua Dr Salvador França 1427, \\ 90690-000 Porto Alegre, Rio Grande do Sul, Brasil.
}

\begin{abstract}
Six mygalomorph spiders species belonging to two families, were collected in the Centro de Pesquisa e Conservação da Natureza Pró-Mata, São Francisco de Paula, state of Rio Grande do Sul, Brazil. Five of those species, five are new. Microstigmatidae: Xenonemesia araucaria sp. nov., males differ from those of $X$. platensis Goloboff, 1988 and $X$. otti Indicatti, Lucas \& Brescovit, 2007 by the curved and very long embolus in the male palp. Females differ from the remaining species of the genus in the seminal receptacle very long and sinuous or twisted. Nemesiidae: Acanthogonatus ericae sp. nov. - males resemble those of $A$. tacuariensis (Pérez-Miles \& Capocasale, 1982) and A. quilocura Goloboff, 1995 by the serrated, curved and long embolus but are distinguished by the presence of a flange on the apex of the embolus. Females differ from the remaining Acanthogonatus by the short copulatory ducts, arising from the apex of the basal dome. Stenoterommata arnolisei sp. nov. is distinguished from the remaining species of the genus by the large sub-apical area of bulb, with a great number of keels, extending to the median region in the male palp and by the long copulatory ducts and spermathecae arising from internal border of basal dome in the female genitalia. S. grimpa sp. nov.: males resemble those of $S$. arnolisei sp. nov. by the shape of the palpal bulb and by the short embolus, but differ in the keels, restricted to the apical region. Females differ from remaining Stenoterommata by the presence of two spermathecae in the rounded fused basal dome. S. curiy sp. nov.: males resemble those of $S$. grimpa sp. nov. by the shape of palpal bulb and the very short embolus, but differ by the translucid keels restricted to the larger distal region. The presence of S. palmar Goloboff, 1995 is confirmed for Brazil. Males of S. palmar are distinguished from the remaining species of the genus by the long, slender and slightly distally curved embolus. Females are distinguished by the single spermathecae arising from the basal third or median area of the long and triangular basal dome. All spiders were collected with pitfall trapping at six distinct areas (two Araucaria forest areas, two secondary forests and two Pinus spp. Silvicultural plantations) over a period of 20 months. Abundance data between areas was compared for $S$. arnolisei sp. nov. and $X$. araucaria sp. nov. based on the mean catches of spiders in each area. No clear habitat preference was shown for each of the species, suggesting broad habitat tolerances. Phenological data were obtained through the abundance in each trapping period; results suggest an overwintering reproductive pattern for S. arnolisei sp. nov. and a spring-summer pattern for $X$. araucaria sp. nov. KEY WORDS. Acanthogonatus; Mygalomorphae; phenology; Stenoterommata; Xenonemesia.
\end{abstract}

RESUMO. Aranhas migalomorfas que habitam a serapilheira (Araneae: Microstigmatidae, Nemesiidae) de florestas de Araucária no sul do Brasil, com a descrição de cinco espécies novas. Seis espécies de aranhas migalomorfas, pertencentes a duas famílias foram coletadas no Centro de Pesquisa e Conservação da Natureza PróMata, São Francisco de Paula, Rio Grande do Sul, Brasil. Destas, cinco são novas. Microstigmatidae: Xenonemesia araucaria sp. nov., machos diferem de X. platensis Goloboff, 1988 e X. otti Indicatti, Lucas \& Brescovit, 2007 pelo êmbolo do bulbo longo e curvado. Fêmeas diferem das outras espécies do gênero pelo receptáculo seminal longo e sinuoso ou espiralado. Nemesiidae: Acanthogonatus ericae sp. nov. - machos se parecem com A. tacuariensis (PérezMiles \& Capocasale, 1982) e A. quilocura Goloboff, 1995 pelo êmbolo longo e curvado, com serrilha na região apical, mas diferencia-se pela presença de uma flange no ápice do êmbolo. Fêmeas diferem do restante das espécies de Acanthogonatus pelos ductos copulatórios curtos, originando-se do ápice da base do domo da espermateca. Stenoterommata arnolisei sp. nov. difere do restante das espécies do gênero pela área subapical do bulbo larga, com um grande número de quilhas, estendendo-se da região mediana no palpo e pelo ducto copulatório longo e espermateca originando-se da borda interna do domo da base da genitália da fêmea. S. grimpa sp. nov.: machos aproximam-se dos

Revista Brasileira de Zoologia 25 (3): 529-546, September, 2008 
de S. arnolisei sp. nov. pela forma do bulbo e pelo êmbolo curto, mas diferem pelas quilhas restritas a região apical. Fêmeas diferem do restante das espécies de Stenoterommata pela presença de duas espermatecas no domo que é arredondado e fundido. S. curiy sp. nov.: machos aproximam-se dos de S. grimpa sp. nov. pela forma do bulbo e pelo êmbolo curto, mas diferem pelas quilhas translúcidas e restritas a região distal que é larga. A presença de $S$. palmar Goloboff, 1995 é confirmada para o Brasil. Machos de S. palmar são distinguidos do restante das espécies do gênero pelo êmbolo longo, delgado e levemente curvado distalmente. Fêmeas são distinguidas pela espermateca de base simples, e originando-se da área do terço basal ou mediano do comprimento e domo basal triangular. Todas as aranhas foram coletadas com armadilhas de solo em seis áreas distintas (duas de floresta com Araucária, duas de floresta secundária e duas de silvicultura de Pinus spp.) em um período de 20 meses. Os dados de abundância entre as áreas foram comparados para S. arnolisei $\mathbf{s p . ~ n o v . ~ e ~} X$. araucaria sp. nov. baseado na média de aranhas capturadas em cada área. Nenhuma preferência de habitat foi notada, sugerindo ampla tolerância das espécies aos habitats. Dados de fenologia foram obtidos diretamente da abundância em cada período de coleta e os resultados sugerem um padrão reprodutivo para o inverno de $S$. arnolisei sp. nov. e entre a primavera e o verão de $X$. araucaria sp. nov. PALAVRAS-CHAVE. Acanthogonatus; fenologia; Mygalomorphae; Stenoterommata; Xenonemesia.

In general, there is little information on the distribution of mygalomorph families in southern Brazil and the majority of the published papers include single descriptions (LuCAs \& INDicatTI 2006, LuCAs et al. 2006, INDICATTI et al. 2007, INDICATTI et al. 2008). From the state of Rio Grande do Sul only two papers list mygalomorph fauna (MELlo-LeiTão 1943, BüCHERL 1952).

Recently, the examination of spiders collected with pitfall traps at the Centro de Pesquisa e Conservação da Natureza PróMata (CPCN Pró-Mata), Potreiro Velho, São Francisco de Paula, state of Rio Grande do Sul, southern Brazil, as well as additional material from this area deposited in several Brazilian arachnological collections, revealed the presence of 12 mygalomorph species belonging to five families: Dipluridae, Idiopidae, Microstigmatidae, Nemesiidae and Theraphosidae. In this paper we deal with those belonging to Microstigmatidae and Nemesiidae. The six species are distributed among the genera Xenonemesia Goloboff, 1988 (Microstigmatidae), Acanthogonatus Karsch, 1880 and Stenoterommata Holmberg, 1880 (Nemesiidae).

Xenonemesia was proposed by Goloboff (1988) based on X. platensis Goloboff, 1988, described from Argentina and Uruguay. This monotypic genus was transferred from Nemesiidae to Microstigmatidae by Goloboff (1995). IndicatTi et al. (2007) recorded the occurrence of $X$. platensis in southern Brazil and described $X$. otti Indicatti, Lucas \& Brescovit, 2007 from the state of Rio Grande do Sul, Brazil. In this paper, Xenonemesia araucaria sp. nov. is described.

Acanthogonatus was proposed by KARSCH (1880), based on A. francki Karsch, 1880, described from Chile. To date, the genus includes 27 species, distributed in Peru, Chile, Brazil, Argentina, and Uruguay (Platnick 2008). Until the present study, A. tacuariensis (Pérez-Miles \& Capocasale, 1982), was the only species of the genus recorded from Brazil. In this paper we describe $A$. ericae sp. nov. from southern Brazil.

Stenoterommata was proposed by Holmberg (1881), based on S. platensis Holmberg, 1881, described from Argentina. To date the genus includes 10 nominal species, distributed in Argentina,
Brazil, and Uruguay (Guadanucci \& Indicatti 2004; Platnick 2008). The distribution of the genus in Brazil reaches from the state of Rio de Janeiro to Rio Grande do Sul. In this paper, three new species are described: $S$. arnolisei sp. nov., S. grimpa sp. nov. and S. curiy sp. nov., the record of S. palmar Goloboff, 1995 in Brazil (Goloboff 1995) is confirmed, and its distribution is extended to the states of Rio Grande do Sul and Santa Catarina.

In addition, ecological data, such as phenology, relative abundance and abundance among different vegetation physiognomies, are presented for each species.

\section{MATERIAL AND METHODS}

The examined material is deposited in the following institutions (abbreviation and curator in parentheses): Instituto Butantan, São Paulo (IBSP, A.D. Brescovit); Museu de Ciências Naturais da Fundação Zoobotânica do Rio Grande do Sul, Porto Alegre (MCN, E.H. Buckup); Museu de Ciência e Tecnologia da Pontifícia Universidade Católica do Rio Grande do Sul, Porto Alegre (MCTP, A.A. Lise); Museu de Zoologia da Universidade de São Paulo, São Paulo (MZSP, R. Pinto da Rocha); Museu Paraense Emílio Goeldi, Belém (MPEG, A.B. Bonaldo); American Museum, New York (AMNH, N. Platnick) and Museo Argentino de Ciencias Naturales "Bernardino Rivadavia", Buenos Aires (MACN, C. Scioscia). Spine notation follows Petrunkevitch (1925). Terminology of genitalia follows GoLobofF (1995) except receptacula (= spermathecae in this work). All measurements are in millimeters and were taken with a millimetric ocular lens. The leg segment length was measured between joints in dorsal view. Length and width of carapace, eye tubercle, labium and sternum are maximum values obtained. The total body length excludes chelicerae, pedicel and spinnerets. All drawings were made with a drawing tube (Leica MZ $12_{5}$ ). Spermathecae were cleared with clove oil and illustrated in frontal and dorsal view. Abbreviations: (AME) anterior median eyes, (ALE) anterior lateral eyes, (PLE) posterior lateral eyes, (PME) posterior median eyes, (PLS) posterior lateral spinnerets,

Revista Brasileira de Zoologia 25 (3): 529-546, September, 2008 
(d) dorsal, (v) ventral, (p) prolateral, (r) retrolateral, (ap) apical, (VP) ventro-prolateral, (VR) ventro-retrolateral.

Ecological data were obtained at "Centro de Pesquisas e Conservação da Natureza Pró-Mata", Potreiro Velho, São Francisco de Paula, state of Rio Grande do Sul, Brazil (29 28'21"S, $\left.50^{\circ} 09^{\prime} 25^{\prime \prime} \mathrm{W}\right)$. The area is characterized mainly by Mixed Ombrophilous Forest (known as Brazilian pine forests or "Floresta com Araucária"); detailed descriptions of the area are provided in Bertoletti \& Teixeira (1997). Six areas, in three distinct forest habitats, under different degrees of anthropic influence, were chosen for this study: two Araucaria angustifolia primary forests (ARA), two secondary forests (SEC) and two pine (Pinus spp.) silvicultures (PIN). In each area, 10 pitfall traps with 10 $\mathrm{cm}$ diameter openings (filled with a $4 \%$ formalin solution) were installed. Traps were kept opened from 22.IX.2000 to 18.V.2002 and were emptied during 18 sampling dates (Tab. I). Due to variations in the number of days between emptying the traps, the seasonal activity abundance of spiders for each sampling period is represented by the relation between the total numbers of spiders for the sample period/total number of sampling days for each trap. Abundance data was compared between areas for $S$. arnolisei sp. nov and $X$. araucaria sp. nov. based on the mean catches of spiders ( \pm standard deviation) in each area. Phenology data was obtained through the period activity abundance at trapping period.

\section{RESULTS \\ Microstigmatidae Xenonemesia Goloboff, 1988}

Xenonemesia Goloboff, 1988: 357. Type-species by monotypy, X. platensis Goloboff, 1988: 358, figs 1-14; Goloboff, 1993: 6, 22; Goloboff, 1995: 5; Indicatti et al. 2007: 44, figs 1-4, 917; Platnick, 2008.

\section{Xenonemesia araucaria sp. nov. Figs 1-14, 30-34, 61-62}

Types. Male holotype, BraziL, Rio Grande do Sul: São Francisco de Paula, (Potreiro Velho, Centro de Pesquisa e Conservação da Natureza Pró-Mata), 02.II.2002, R. Ott leg., deposited in MCN 42910; Paratypes: same data of holotype, male, 09.VIII.2001 (MCN 42911); female, 14.IX.2001 (MCN 42912); male, 11.X.2001 (IBSP 113612); female, 25.X.2000 (IBSP 113613); male, 23.XI.2000 (MCTP 20458); female, 02.II.2001 (MCTP 20459); male and female, 25.X.2000 (MZSP 28853; 28854); male; 01.IX.2001 (MPEG 011721); female, 01.II.2002 (MPEG 011722); male, 01.X.2000 (AMNH); female, 13.XI.2001 (AMNH).

Etymology. The specific name is a noun in apposition that refers to the kind of habitat in which this species is the second most common, Araucaria angustifolia (Bertol.) O. Kuntze (Araucariaceae) forest.

Table I. Seasonal record of the number of less-abundant species of Acanthogonatus and Stenoterommata (Nemesiidae), collected in CPCN Pró-Mata, São Francisco de Paula, Rio Grande do Sul, between 22.IX.2000 and 18.V.2002.

\begin{tabular}{|c|c|c|c|c|c|c|c|c|}
\hline \multirow{2}{*}{ Data amostral } & \multicolumn{2}{|c|}{ A. ericae sp. nov. } & \multicolumn{2}{|c|}{ S. curiy sp. nov. } & \multicolumn{2}{|c|}{ S. grimpa sp. nov. } & \multicolumn{2}{|c|}{ S. palmar } \\
\hline & Male & Female & Male & Female & Male & Female & Male & Female \\
\hline $25 . X .2000$ & & 1 & 1 & & & & 1 & \\
\hline 23.XI.2000 & 1 & & & & & & 1 & \\
\hline 02.1 .2001 & & & & & & & & 1 \\
\hline 02.II.2001 & & 1 & & & & & & 1 \\
\hline \multicolumn{9}{|l|}{ 03.III.2001 } \\
\hline \multicolumn{9}{|l|}{ 07.IV.2001 } \\
\hline \multicolumn{9}{|l|}{ 01.V.2001 } \\
\hline 02.VI.2001 & & & & & & & 2 & \\
\hline 07.VII.2001 & 1 & 1 & 1 & & 1 & 1 & 2 & \\
\hline 09.VIII.2001 & & & 2 & & & & 1 & \\
\hline 14.IX.2001 & & & 1 & & & & 2 & \\
\hline 11.X.2001 & & & & & & & 2 & \\
\hline 13.XI.2001 & 2 & & & & & & & \\
\hline \multicolumn{9}{|l|}{ 15.XII.2001 } \\
\hline \multicolumn{9}{|l|}{02.11 .2002} \\
\hline \multicolumn{9}{|l|}{ 08.III.2002 } \\
\hline \multicolumn{9}{|l|}{ 14.IV.2002 } \\
\hline \multicolumn{9}{|l|}{ 18.V.2002 } \\
\hline$\Sigma$ & 4 & 3 & 5 & 0 & 1 & 1 & 11 & 2 \\
\hline
\end{tabular}


Diagnosis. Males of Xenonemesia araucaria sp. nov. differ from those of $X$. platensis (see Goloboff 1988, figs 1-14) and $X$. otti (see InDicatTr et al. 2007, figs 5-7) by the curved and very long embolus (Figs 1, 2 and 5) in the male palp. Females differ from the remaining species of the genus by the seminal receptacle very long and sinuous (Fig. 3) or twisted (Fig. 4).

Description. Male (holotype). Coloration pattern: carapace orange brown and legs brown with dark brown stains (Fig. 30). Abdomen dark yellow with symmetrical black stains (Figs 30 and 33-34). Total length 8.5. Carapace 4.3 long, 3.7 wide, with short and procurved fovea. Clypeus narrow 0.24. Anterior eye row procurved, posterior slightly recurved. AME smaller than ALE, ALE larger than PLE and PME smaller than PLE. Overall shape of eye group trapezoidal, wider than long in ratio. Basal segment of chelicerae with seven teeth in one row on the prolateral margin and rastellum with very strong setae. Intercheliceral tumescence small, pale yellow covered with few hairs. Labium 0.4 long, 0.5 wide, without cuspules (Fig. 32). Each endite with 16 cuspules. Serrula absent. Sternum circular 2.2 long, 1.9 wide. Six sternal sigilla, posterior submarginal twice the size of anterior (Fig. 32). Palp: measurements: femur 1.9/ patella 0.8 /tibia $1.5 /$ cymbium 0.8 /total 5.0 ; spination: femur d1-1-1-1-2-3. Legs: measurements: I: femur 3.0/patella 2.0/tibia 2.1/metatarsus 1.9/tarsus 1.3/total 10.3; II: 2.5/1.9/1.5/1.8/1.2/ 8.9; III: 2.4/1.8/1.2/2.1/1.0/8.5; IV: 3.2/2.0/2.1/3.0/1.3/11.6; spination: I: femur d1-1-1-2, tibia v3-2-3, p2, megaspine absent, metatarsus v2-2-2, p1; II: femur d1-1-1-1-2, patella p1, tibia d1p-1p, v2-1r-2, p1 metatarsus v1r-2-3, p0-1-1, r1; III: femur d1-1r-2, patella d2-2-1p, r1-1-2, tibia d1-1, v2-2-2, p1-2-1, r1-1, metatarsus d1-2-1, v2-2-2, p1-1-1, r1-1-1; IV: femur d1-11r, patella r1, tibia d1, v2-2-2, p1-1-1, r1-1, metatarsus d1-1, v2-2-3, p1-1-1, r1-1-1. Tarsi I-IV not flexible. Scopulae present on tarsi I-III and laterally on tarsi III. Superior tarsal claws large with a double row of 5-6 teeth on tarsi I-II, 7 on III and 7-9 on IV. Third claw absent on all tarsi. Four spinnerets, PLS three segmented, basal segment 0.32 , median segment 0.24 , apical
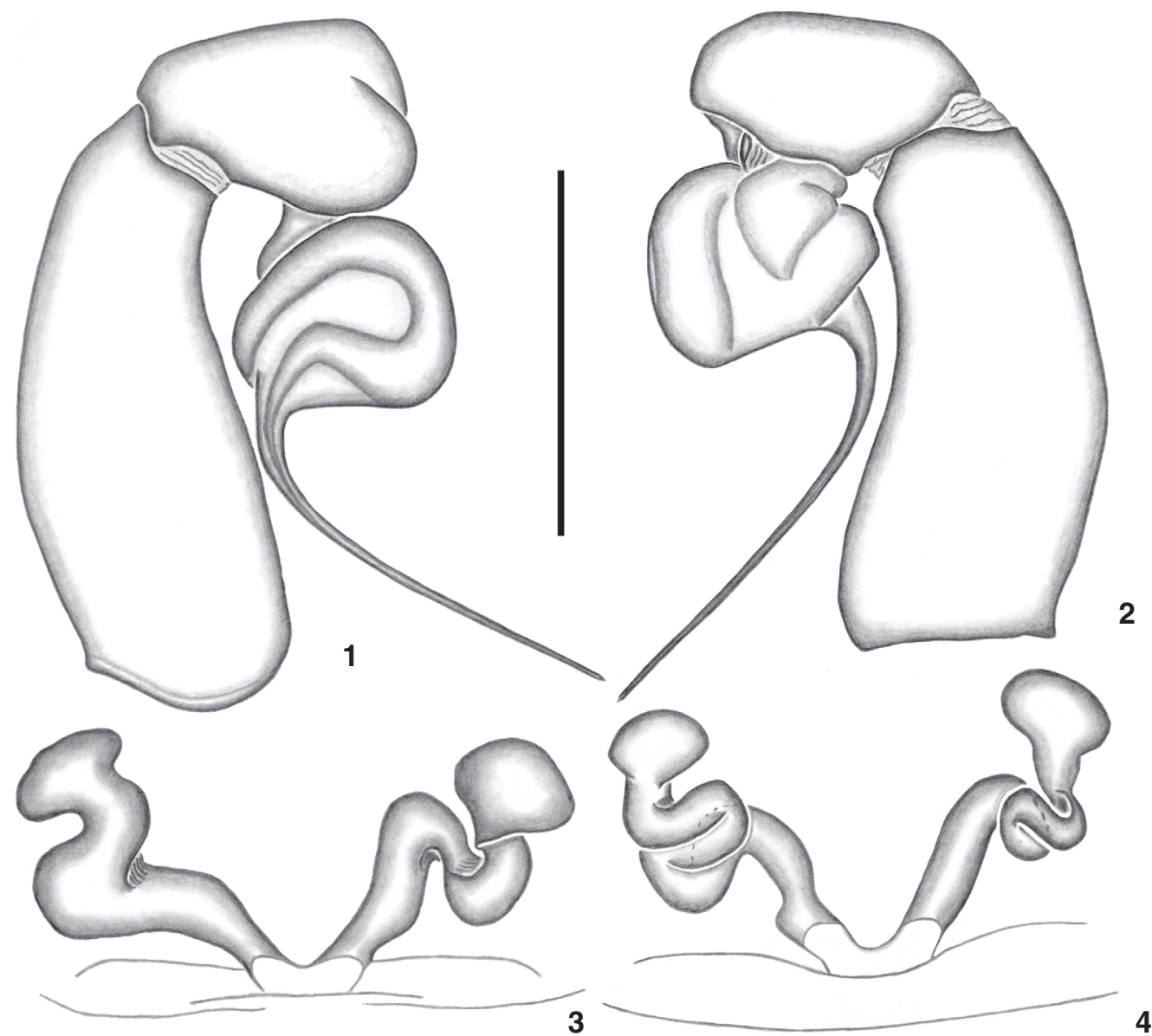

Figures 1-4. Xenonemesia araucaria sp. nov. (1-2) Male, left palpal bulb; (1) prolateral view; (2) retrolateral view; (3-4) female, spermathecae variation; (3) dorsal view; (4) dorsal view. Scale bars = $1 \mathrm{~mm}$. 

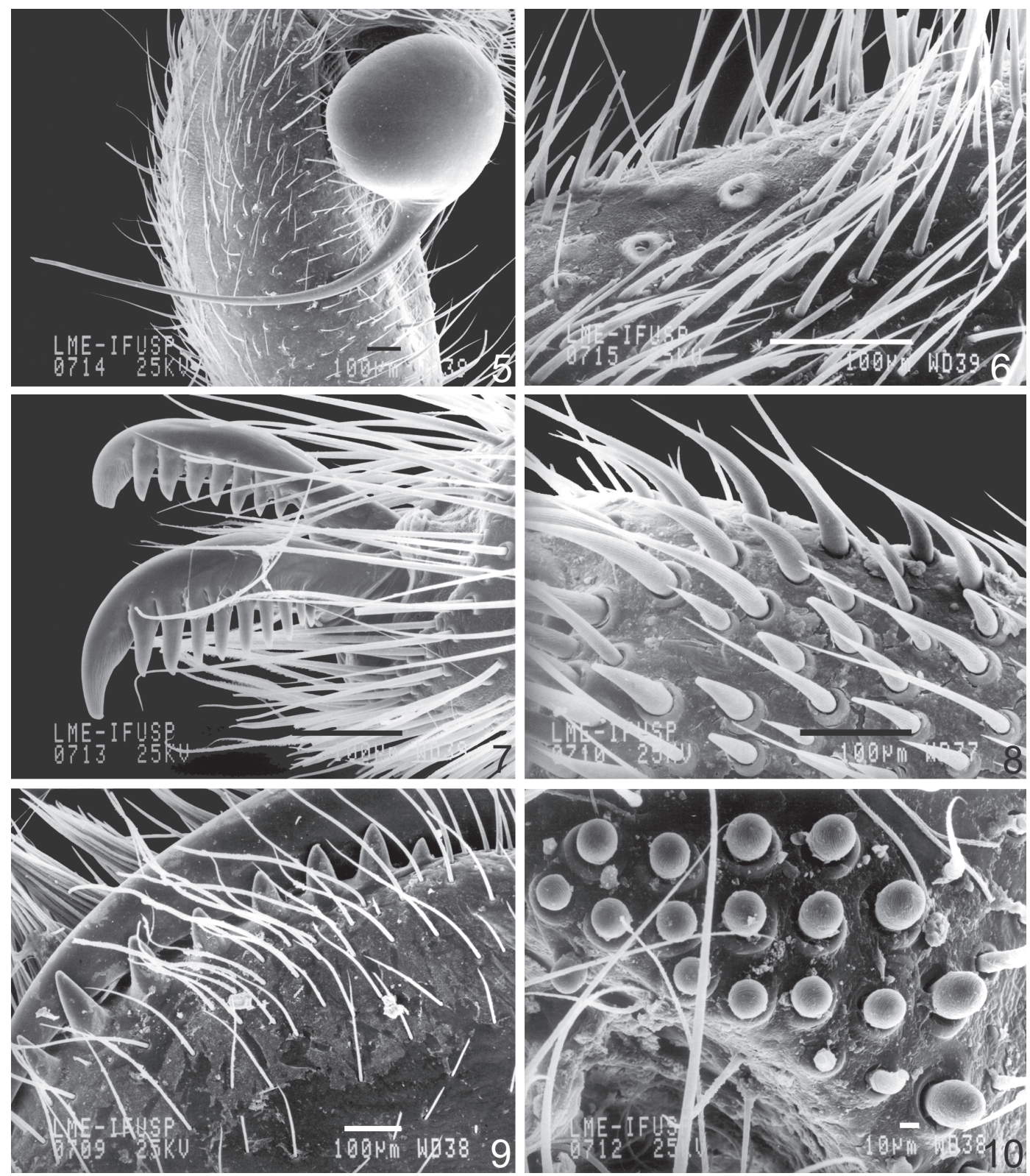

Figures 5-10. Xenonemesia araucaria sp. nov. (5) Male, left palpal bulb, retrolateral view; (6) Cymbium, trichobothria, dorsal view; (7) tarsal claw IV, retrolateral view; (8) Chelicerae, rastellum, frontal view; (9) basal segment of chelicerae, teeth, prolateral view; (10) Endites, cuspules, dorsal view. Scale bars: $(5-9)=100 \mu \mathrm{m} ;(10)=10 \mu \mathrm{m}$

segment domed 0.12 long. Palpal bulb globose (Figs 1 and 2) Female (paratype MCN 42911). Coloration as in male (Fig. 31). Total length 12.0. Carapace 5.4 long, 4.4 wide, with short and procurved fovea. Clypeus narrow 0.32. Eyes as in male. Basal segment of chelicerae with eight teeth in one row on the prolateral margin and rastellum with very strong setae. Intercheliceral tumescence absent. Labium 0.4 long, 0.9 wide, without cuspules. Endites with 22/25 cuspules. Sternum circular 2.2 long, 2.4 wide. Six sternal sigilla, posterior and median submarginal, posterior twice the size of anterior. Palp: measurements: femur 2.1/patella 1.1/tibia 2.2/cymbium 1.3/total 5.7; spination: femur d1-1-1-3, tibia v2. Legs: measurements: I: femur 3.0/patella 2.4 /tibia 1.8 /metatarsus 1.4 /tarsus $1.0 /$ total 9.6; II: 2.7/2.0/1.5/1.5/1.0/8.8; III: 2.3/1.8/1.1/1.7/1.2/8.1; IV: 3.3/ 2.3/2.1/2.9/1.3/11.9; spination: I: femur d1-1-1-2; II: metatarsus v1r-2; III: femur d1-1-2, patella p1-1-1, r1-1, tibia d1-1, v2,

Revista Brasileira de Zoologia 25 (3): 529-546, September, 2008 


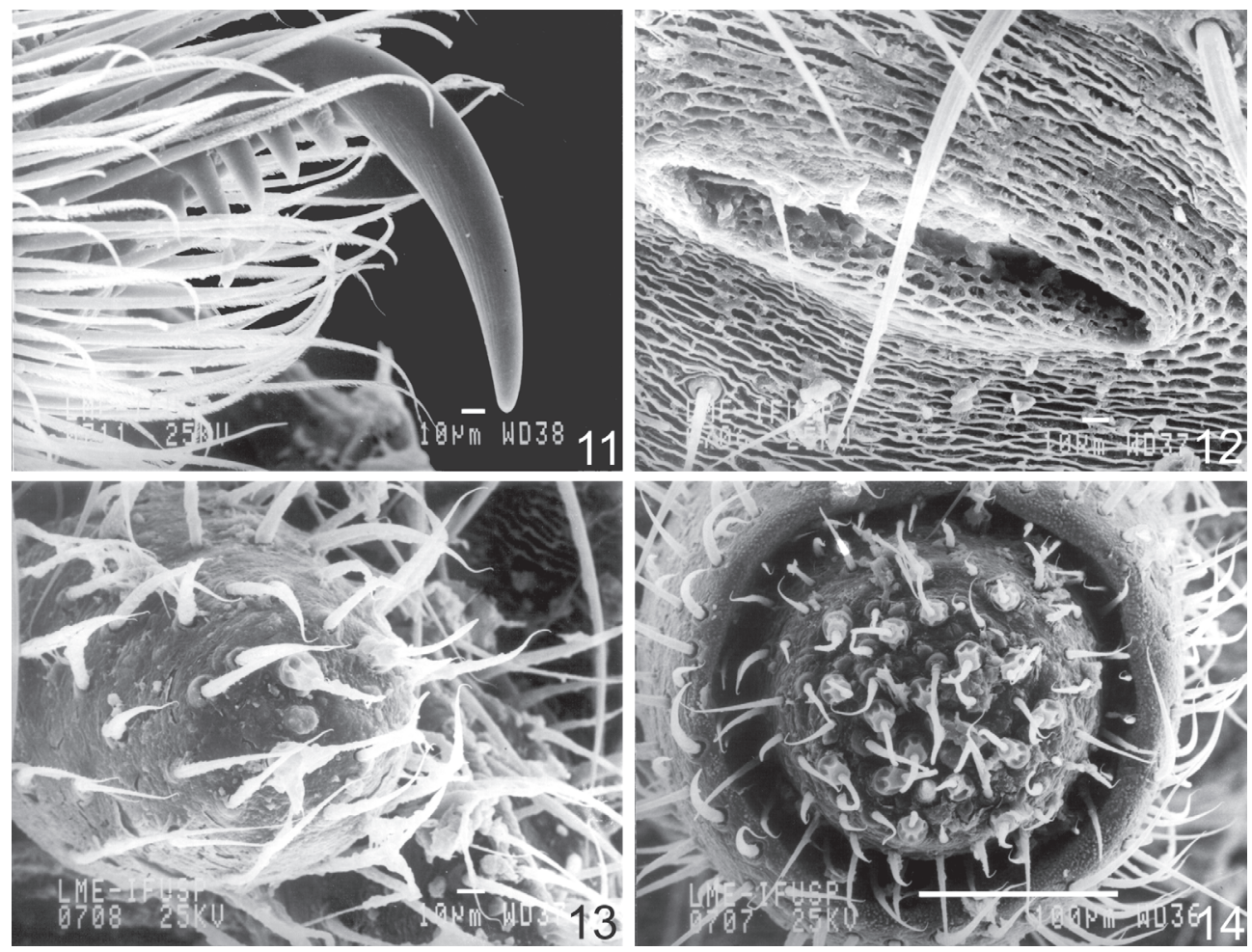

Figures 11-14. Xenonemesia araucaria sp. nov. (11) Male, palpal claw, prolateral view; (12) Male, book lung openning, dorsal view; (13) posterior lateral spinnerets, median apical article, frontal view; (14) posterior lateral spinnerets, posterior apical article, frontal view. Scale bars: $(11-13)=10 \mu \mathrm{m} ;(14)=100 \mu \mathrm{m}$.

p1-1-1, metatarsus d1-2-2, v2-3, p1-1-1, r1-1-1; IV: femur d1-11-2, tibia v1-2, p1-1-0, r1-1-0, metatarsus d1-2-2, v2-2-3, p1-11, r1-1-1. Palp with a row of five prolateral teeth. Tarsi I-IV not flexible. Scopula present on tarsi I-II and $1 / 3$ of metatarsi I. Scopula of tarsi II divided by few rows of thin setae. Superior tarsal claws large with a double row of two teeth on tarsi I, three on II, 3-4 on III-IV. Third claw absent on all tarsi. Four spinnerets, PLS three segmented, basal segment 0.52, median segment 0.24 , apical segment domed 0.16 long. Female genitalia (Figs 3 and 4) with oval spermathecae (= receptacula in Golobof 1995).

Variation. Males $(n=20)$ : total length 8.0-10.00; carapace 4.1-5.2; femur I: 2.8-3.2. Females $(\mathrm{n}=10)$ : total length 9.4-12.0; carapace 4.5-5.8; femur I: 2.7-3.0. Endites with 15-20 cuspules on males and 20-25 on females.

Additional material examined. BraziL, Rio Grande do Sul: São Francisco de Paula (Potreiro Velho, Centro de Pesquisa e Conservação da Natureza Pró-Mata), 2 males and 1 female, 13.XI.2001 (IBSP 113615; 113616); 1 male, 25.X.2000 (IBSP 113617); 32 males and 17 females, 25.X.2000-18.V.2002 (MCTP), all collected by R. Ott.

Distribution. Known from southern Brazil, state of Rio Grande do Sul.

\section{Nemesiidae Acanthogonatus Karsch, 1880}

Acanthogonatus Karsch, 1880: 391. Type-species by monotypy, A. francki Karsch, 1880: 392; Raven, 1985: 83; Goloboff, 1995: 72; Platnick, 2008.

\section{Acanthogonatus ericae sp. nov. Figs 15-26, 35-39}

Types. Male holotype, BraziL, Rio Grande do Sul: São Francisco de Paula, (Potreiro Velho, Centro de Pesquisa e Conservação da Natureza Pró-Mata), 25.X.2001, R. Ott leg., deposited in MCN 42903; Paratypes: same data of holotype, 1 female, 02.II.2001 (MCN 42904); 1 male, 01.X.2001 (IBSP 113566); 1 female, 23.XI.2000 (IBSP 113567); 1 male and 1 female, 07.VII.2001 (MCTP 20464; 20465), all collected by R. Ott.

Etymology. The specific name honors Erica Helena Buckup, Brazilian arachnologist and curator of the MCN collection.

Diagnosis. Males of Acanthogonatus ericae sp. nov. resemble those of A. tacuariensis (Pérez-Miles \& Capocasale, 1982) and $A$. quilocura Goloboff, 1995 by the serrated, curved and long embolus (see Goloboff 1995: 86, figs 83 B-C and 85 B-C) but are distinguished by the presence of a flange on the apex

Revista Brasileira de Zoologia 25 (3): 529-546, September, 2008 


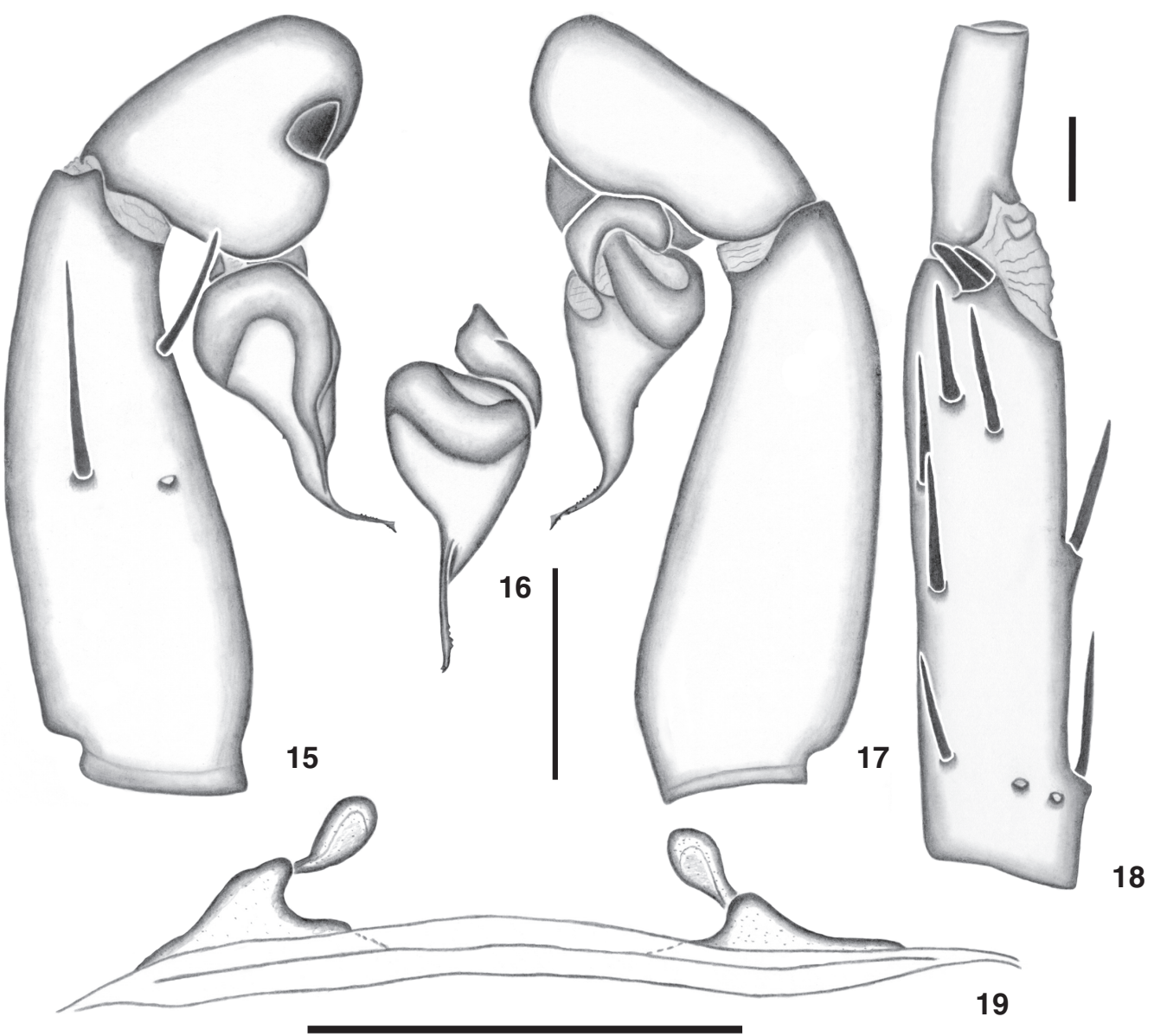

Figures 15-19. Acanthogonatus ericae sp. nov. (15-17) male, left palpal bulb; (15) prolateral view; (16) ventral view; (17) retrolateral view; (18) male, tibia I, prolateral view; (19) female, spermathecae, dorsal view. Scale bars $=1 \mathrm{~mm}$.

of the embolus (Figs 15-17 and 20-21). Females (Fig. 19) differ from the remaining Acanthogonatus by the short copulatory ducts, arising from the apex of the basal dome.

Description. Male (holotype). Coloration pattern: carapace orange brown, femur I-IV brown, patella, tibia, metatarsus and tarsus I-IV dark brown. Abdomen dorsally dark brown and ventrally yellowish brown (Figs 35-39). Total length 17.2. Carapace 8.5 long, 7.0 wide, short and procurved fovea (Fig. 35). Clypeus narrow 0.4 . Anterior eye row slightly procurved, posterior slightly recurved. AME smaller than ALE, ALE larger than PLE and PME smaller than PLE. Overall shape of eye group trapezoidal, wider than long in ratio. Basal segment of chelicerae with eight teeth in one row on the prolateral margin and rastellum with very strong setae. Intercheliceral tumescence small, pale covered by few hairs. Labium 1.1 long, 0.6 wide, without cuspules. Endites with 15/21 cuspules. Serrula present. Sternum oval 3.0 long, 1.2 wide. Six sternal sigilla, posterior submarginal twice the size of anterior (Fig. 37). Palp: measurements: femur 3.7/patella 2.1/ tibia 2.6/cymbium 1.3/total 9.7; spination: tibia r1. Legs: mea- surements: I: femur 6.7/patella 4.7/tibia 4.7/metatarsus 5.6/tarsus 4.3/total 26.0; II: 6.6/4.3/4.5/5.2/4.2/24.8; III: 6.0/3.2/4.0/ 5.5/3.6/22.3; IV: 7.7/3.9/5.6/7.8/4.5/29.5; spination: I: femur d11r-2, patella p1, tibia v1-2-1r-2-1r, p1-1-2 two megaspine, r1; II: femur d1-1-1-1, patella p1, tibia v2-2-2, p1-1-1, metatarsus v1r2, p1; III: femur d1p-2-1r-1r, patella r1, tibia d1, v2-2-2, p1-1-0, 1-1-0, metatarsus d1r-2-2-2-1r, v2-2-2-1r, p1-1-1, r1-1-1; IV: femur d1-1-1p-2, patella r1, tibia v2-2-2, p1-1-0, r1-1, metatarsus d2-2-2-2, v2-1p-2-2, p1-1-1, r1-1-1. Tarsi I-IV flexible (Fig. 39). Scopulae entire present on tarsi I-IV, on metatarsi I-II and on half of metatarsi III. Superior tarsal claws large with a double row of 9-10 teeth on tarsi I and IV, 8-9 on II, 7-8 on III. Third claw absent on tarsi I-IV. Four spinnerets, PLS three segmented, basal segment 1.5, median segment 1.1, apical segment digitiform 1.5 long. Palpal bulb piriform, embolus with at least 10 denticles (Figs 15-17 and 20-21).

Female (paratype MCN 42904). Coloration as in male (Figs 35-39). Total length 23.0. Carapace 11.0 long, 8.5 wide, with short and procurved fovea. Clypeus narrow 0,5. Eyes as in male. Basal 


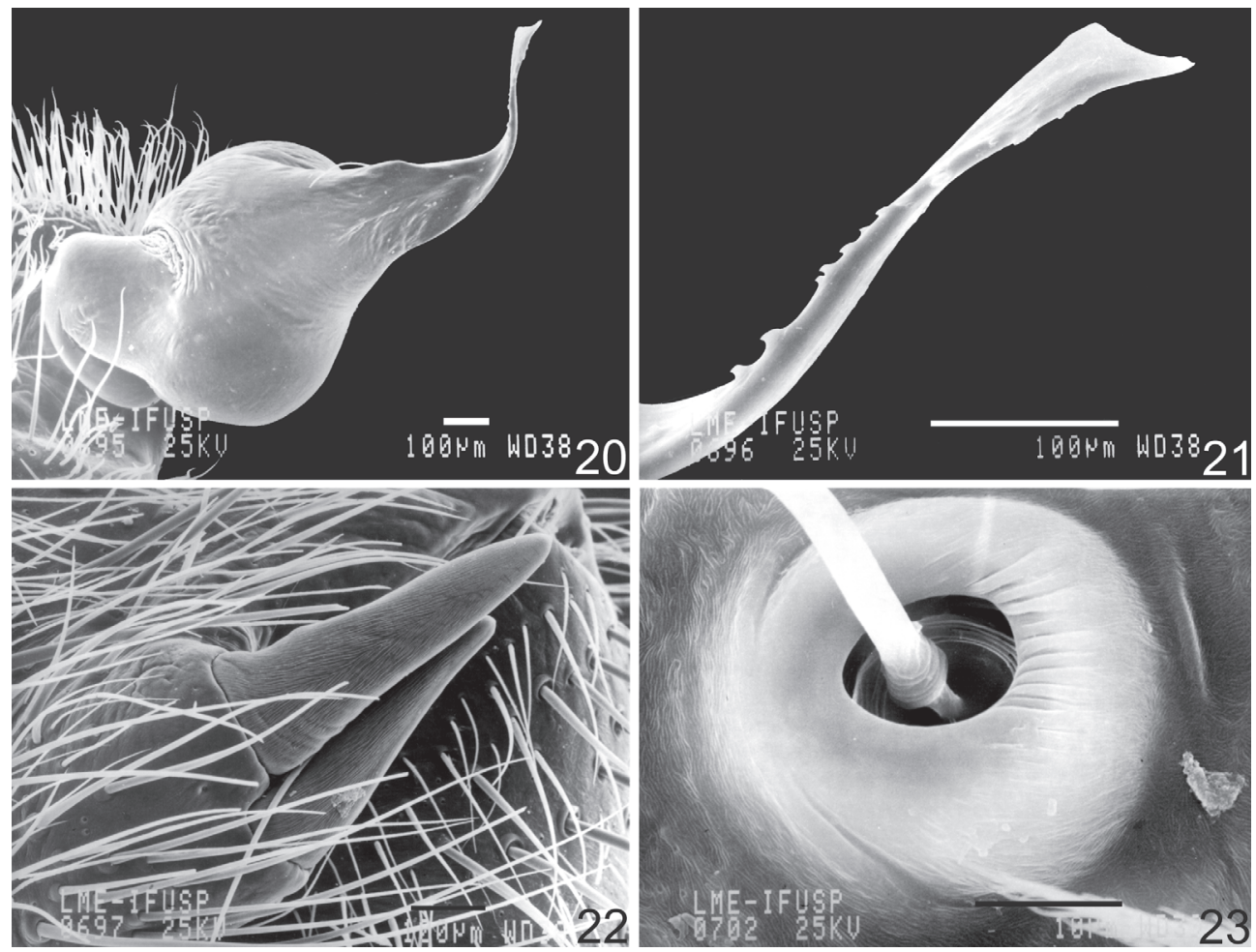

Figures 20-23. Acanthogonatus ericae sp. nov. (20-21) male, right palpal bulb; (20) retrolateral view; (21) embolus, detail of tip, retrolateral view; (22) male, tibia I, clasping spines, prolateral view; (23) tarsus I, trichobothria, dorsal view. Scale bars $(20-21)=100 \mu \mathrm{m} ;(23)=10 \mu \mathrm{m}$.

segment of chelicerae with nine teeth in one row on the prolateral margin and rastellum with very strong setae. Intercheliceral tumescence absent. Labium 0.7 long, 1.5 wide, with one cuspule. Endites with 28/36 cuspules. Serrula absent. Sternum oval 4.6 long, 3.8 wide. Six sternal sigilla, posterior submarginal three times the size of anterior. Palp: measurements: femur 3.7/patella 2.0/ tibia 2.5/cymbium 2.3/total 10.5; spination: femur p1, tibia v22-2, p1-1, r1. Legs: measurements: I: femur 5.5/patella 3.8/tibia 3.5/metatarsus 3.6/tarsus 2.5/total 18.9; II: 5.0/3.4/3.2/3.3/2.5/ 17.4; III: 4.4/2.3/2.8/3.9/2.6/16.1; IV: 5.6/2.9/4.0/5.6/3.3/21.4; spination: I: femur d1-1, p1, tibia v1r-1r-2, p1, megaspine absent, metatarsus v1r, p1; II: femur d1-1-1p, tibia v1r-1r-2, p1-1, metatarsus v1r-1r; III: femur d1-2, tibia v1r-2, p1-1, r1, metatarsus d2-2-2, v1p-2-2, 1-1-1, r1-1-1; IV: femur d1-1-1p, tibia v1r-1r2, p1, r1-1, metatarsus d2-2-2, v1p-1p-2-2, p1-1-1, r1-1-1. Pedipalp with one row with four teeth and 16 basal granules. Tarsi IIV flexible. Metatarsi III 4/5 scopulate only on prolateral side. Scopula of tarsi IV divided by a row of thin setae and $1 / 4$ scopulae present on metatarsi. Superior tarsal claws large with a double row of 4-6 teeth on tarsi I, 5-6 on II and III, 5-7 on IV. Third claw absent on all tarsi. Four spinnerets, PLS three segmented, basal segment 1.5, median segment 1.2, apical segment digitiform 1.8 long. Female genitalia with a triangular separated basal dome; with short copulatory ducts and oval spermathecae (Fig. 19).
Variation. Males $(\mathrm{n}=3)$ : total length 17.2-18.0; carapace 8.5-9.0; femur I: 6.7-6.8. Endites with 15-22 cuspules.

Additional material examined. BraziL, Rio Grande do Sul: São Francisco de Paula (Potreiro Velho, Centro de Pesquisa e Conservação da Natureza Pró-Mata), 1 male, 23.XI.2000, R. Ott leg. (MCTP 20466).

Distribution. Known from southern Brazil, state of Rio Grande do Sul.

\section{Stenoterommata Holmberg, 1881}

Stenoterommata Holmberg, 1881: 126. Type-species by original designation, S. platensis Holmberg, 1881: 126, pl. 1, f. 1; Raven, 1985: 106; Goloboff, 1995: 57; Platnick, 2008.

\section{Stenoterommata palmar Goloboff, 1995 Figs 40-47}

Stenoterommata sp.: Goloboff, 1988: 362.

Stenoterommata palmar Goloboff, 1995: 69, fig. 73 A-F (Male holotype and female paratype, Argentina, Entre Ríos (Parque Nacional El Palmar), deposited in MACN 9614 and 9619, examined); Platnick, 2008.

Diagnosis. Males of Stenoterommata palmar are distinguished from the remaining species of the genus by the long,

Revista Brasileira de Zoologia 25 (3): 529-546, September, 2008 
slender and slightly distally curved embolus (Figs 40-42). Females are distinguished by the single spermathecae arising from the basal third or median area of the long and triangular basal dome (Figs 43-47).

Description. Male and female described by GoLoboff (1995: 69-71, fig. 73 A-F). Palp and female genitalia as in figures 40-47.

Variation. Males $(\mathrm{n}=11)$ : total length 8.75-11.4; carapace 4.05-5.9; femur I: 3.05-5.7. Females $(n=9)$ : total length 9.8-15.5; carapace 3.7-6.8; femur I: 1.55-4.2.

Note. Before the examination of the specimens collected in southern Brazil and of the female paratype of $S$. palmar (MACN 9619), we noted that the illustration presented by Goloboff (1995: 69, fig. 73 F) was incomplete. In this paper we present complete illustrations depicting five possible variations of the genitalia of $S$. palmar (Figs 43-47).

New records. BraziL. Santa Catarina: Rio Negrinho, 1 male, VI.2004-VII.2005, M.A. Nickerle leg. (IBSP 115436); Florianópolis (Praia do Campeche), 2 males and 1 female, VI-VIII.2006, F. Albertoni leg. (IBSP 113034-113036); (Costa do Santinho, Morro das Aranhas), 1 female and 1 juvenile, III.2007, L. Zanella leg. (IBSP 113968); (Itacurubi, UCAD), J. Steiner leg., 3 males and 1 female, 01-08.IX.2003 (IBSP 114345; 114347); 3 males, 0310.XI.2003 (IBSP 114348; 114349); 1 female, 2004 (IBSP 91100); 2 males, 05-12.I.2004 (IBSP 114341; 114342); 1 female, 0310.II.2004 (IBSP 114346); 1 male and 1 female, 01-08.IX.2003 (IBSP 114343; 114322); 2 males, 03-10.X.2003 (IBSP 114320; 114321); 1 male, 23-29.VII.2004 (IBSP 114340); Paulo Lopes (Parque Estadual do Tabuleiro, $27^{\circ} 55^{\prime} \mathrm{S}-48^{\circ} 42^{\prime} \mathrm{W}$ ), 2 females, 10 20.I.2003, Equipe Biota leg. (IBSP 112717; 112720); Blumenau (Parque Natural Municipal Nascentes do Rio Garcia, $27^{\circ} 01^{\prime} \mathrm{S}$ $49^{\circ} 09^{\prime} \mathrm{W}$ ), 1 female, 21-28.I.2003, Equipe Biota leg. (IBSP 113100); 4 males, 18.V.2004-28.II.2005, R.C. Francisco leg. (IBSP 114745114747; 114749); Laguna (Bentos), 1 male and 1 female, I.2003, Equipe Biota leg. (IBSP 115352; 115353); Urussanga (Rio Molha), R. Teixeira leg., 1 female, III.2007 (IBSP 114698); 1 male and 1 juvenile (IBSP 114699); 1 female, 10-17.XII.2007 (IBSP 114700); 1 female, 4-11.IX.2007 (IBSP 114701); 1 female and 4 juveniles, 19-26.VI.2007 (IBSP 114703). Rio Grande do Sul: São Francisco de Paula (Potreiro Velho, Centro de Pesquisa e Conservação da Natureza Pró-Mata), 1 male, 02.VI.2001, R. Ott leg. (IBSP 113630); 1 male, 09.VIII.2001 (IBSP 113631); 1 male, 14.IX.2001 (IBSP 113568); 1 male, 02.VIII.2001 (IBSP 113569); 9 males, 25.X.200011.X.2001 (МСTP); 1 male, 25-28.IV.1996, A.A. Lise leg. (MCTP 9863); (Floresta Nacional de São Francisco de Paula), 1 female, VIII.2003, F. Joner leg. (MCN 42921); (Potreiro Velho), 1 male and 1 female, 22.IV.1997, J. Ketterl leg. (MCTP 17491); 1 male, 11.VI.1997 (MCTP 17501); 1 female, 11-14.IX.1997, A.A. Lise leg. (MCTP 14419); 5 males, IV.2002, L.A. Bertoncello \& A.A. Lise leg. (MCTP 18433; 18434; 19396; 19397; 19398); 3 males, V.2002 (MCTP 19399-19401); 3 males, VI.2002 (MCTP $19402-$ 19404); 2 males, VII.2002 (MCTP 19405-19406); 4 males, VIII.2002 (MCTP 19407-19410); 1 male, IX.2001 (MCTP 19412); 5 males, X.2001 (MCTP 19413-19417); 3 males, XI.2001 (MCTP
19418; 19419; IBSP 113632); (Salto), 1 male, 05.V.2003, G. M. Petersen leg. (MCTP 16743); Maquiné, 1 male, 08.IV.1995, L. Moura leg. (MCN 26566); (FEPAGRO, 29³9'S-50²12'W), 5 females, 18-27.I.2002, Equipe Biota leg. (IBSP 112723-112727); Santana do Livramento (Estância Bela Vista), 1 male, 15.IV.2005, Miganom leg. (IBSP 114294).

Natural history. Two males were collected on trunks of Araucaria angustifolia trees in the CPCN Pró-Mata, with upwards arboreal photoecletors placed $1.5 \mathrm{~m}$ above ground (for more details see BREsCovit et al. 2004).

Distribution. Known from Argentina and southern Brazil, states of Santa Catarina and Rio Grande do Sul.

\section{Stenoterommata arnolisei sp. nov. Figs 27-29, 48-51, 61-62}

Types. Male holotype, Brazil, Rio Grande do Sul: São Francisco de Paula, (Potreiro Velho, Centro de Pesquisa e Conservação da Natureza Pró-Mata), 13.XI.2001, R. Ott leg., deposited in MCN 42907; Paratypes: same data of holotype, 1 female, 03.III.2001 (MCN 42909); 1 male, 09.VIII.2001 (MCN 42908); 1 male, 01.V.2001 (IBSP 113618); 1 female, 14.IV.2002 (IBSP 113619); 1 male, 07.VII.2001 (IBSP 113620); 1 male, 02.VI.2001 (MCTP 20467); 1 female, 11.X.2001 (MCTP 20468); 1 male, 08.III.2002 (MPEG 011723); 1 female (MPEG 011724);1 male, 14.IV.2002 (MZSP 28855); 1 female, 03.III.2001 (MZSP 28856); 1 male, 14.IV.2002 (AMNH); 1 female, 02.II.2002 (AMNH); (Potreiro Velho), 1 male, IV.2002, L. A. Bertoncello leg. (MCTP 18430); 1 male (MCTP 18431); 1 male, 03.VI.1997, J. Ketterl leg. (МСTP 17489); 2 females, 10.XI.1995, M. Di Bernardo leg. (MCTP 9571).

Etymology. The specific name honours Dr. Arno Antonio Lise, Brazilian arachnologist and curator of the MCTP collection.

Diagnosis. Stenoterommata arnolisei sp. nov. is distinguished from the remaining species of the genus by the large sub-apical area of bulb, with a great number of keels, extending to the median region (Figs 27 and 48-50) in the male palp and by the long copulatory ducts and spermathecae arising from internal border of basal dome (Fig. 51) in the female genitalia.

Description. Male (holotype). Coloration pattern: carapace yellowish brown, legs brown. Abdomen dorsally brown with symmetrical pale yellow stains and ventrally yellow with four distal black stains. Total length 10.0. Carapace 5.4 long, 4.2 wide, with short and slightly procurved fovea. Clypeus narrow 0.26 . Anterior eyes row procurved, posterior slightly recurved. AME smaller than ALE, ALE larger than PLE and PME smaller than PLE. Overall shape of eye group trapezoidal, wider than long in ratio. Basal segment of chelicerae with 11 teeth in a row on the prolateral margin and rastellum with very strong setae. Intercheliceral tumescence small, pale covered by few hairs. Labium 0.4 long, 0.8 wide, without cuspules. Endites with $76 / 78$ cuspules. Serrula present. Sternum oval 2.5 long, 2.1 wide. Six sternal sigilla marginal, posterior twice the size of anterior. Palp: measurements: femur 2.7/patella 1.7/tibia 2.0/cymbium

Revista Brasileira de Zoologia 25 (3): 529-546, September, 2008 

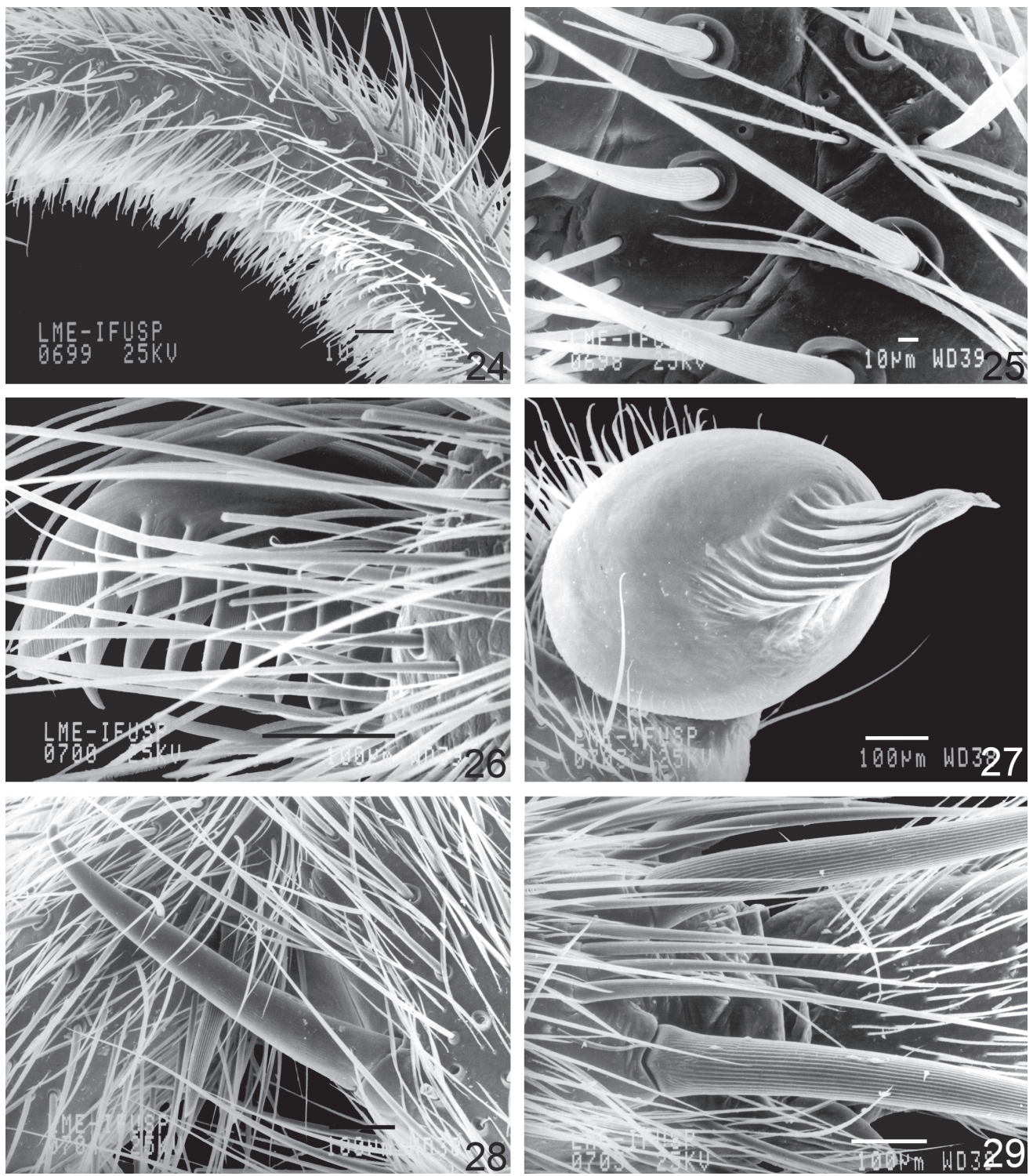

Figures 24-29. Acanthogonatus ericae sp. nov. and Stenoterommata arnolisei sp. nov. (24-26) Acanthogonatus ericae sp. nov.; (24-26) male tarsus I, retrolateral view; (24) flexible; (25) detail flexible; (26) tarsal claw; (27-29) Stenoterommata arnolisei sp. nov.; (27) male, right palpal bulb; (28) tibia I, megaspine, retrolateral view; (29) metatarsus III, preening combs, ventro-retrolateral view. Scale bars (24, $26-29)=100 \mu \mathrm{m} ;(25)=10 \mu \mathrm{m}$.

1.0/total 7.4; spination: femur d1-1-1-3, tibia d2, p1. Legs: measurements: I: femur 4.1 /patella $2.7 /$ tibia $2.8 /$ metatarsus $3.2 /$ tarsus $2.1 /$ total 14.9 ; II: 3.6/2.6/2.4/2.8/2.1/13.5; III: 3.5/1.7/ 2.1/3.5/1.8/12.6; IV: 4.3/1.8/3.4/5.3/2.1/16.9; spination: I: femur d1-1-1-3, tibia v1r-2r-2, p1-1, megaspine present (Fig. 28), metatarsus v2-2-1r, p1-1; II: femur d1-1-1-1p-3, tibia v1r-1r-2, p-1-1, metatarsus v1r-2-2, p1-1; III: femur d1-3-1-1-2-1p, patella d2-2, tibia d1, v2-2-2, p1-1, r1-1-1, metatarsus d1-2-2, v22-2, p1-1-1, r1-1-1; IV: femur d1-1-1-1p-2, patella d2, tibia v2-
2-2, p1-1, r1-1, metatarsus d2-2-2, v2-2-2, p1-1-1, r1-1-1. Metatarsal preening combs on legs III: 4VP, 4VR (Fig. 29) and IV: 3VP, 3VR. Tarsi III-IV flexible. Scopulae present on tarsi I-III and half of metatarsi I-II. Superior tarsal claws large with a double row of 6 teeth on tarsi I, 5-6 on tarsi II, 8-11 on tarsi III, 8-10 on tarsi IV. Third claw on tarsi I-IV. Four spinnerets, PLS three segmented, basal segment 0.8 , median segment 0.6 , apical segment triangular 0.7 long. Palpal bulb globose with a very short embolus (Figs 48-50).

Revista Brasileira de Zoologia 25 (3): 529-546, September, 2008 

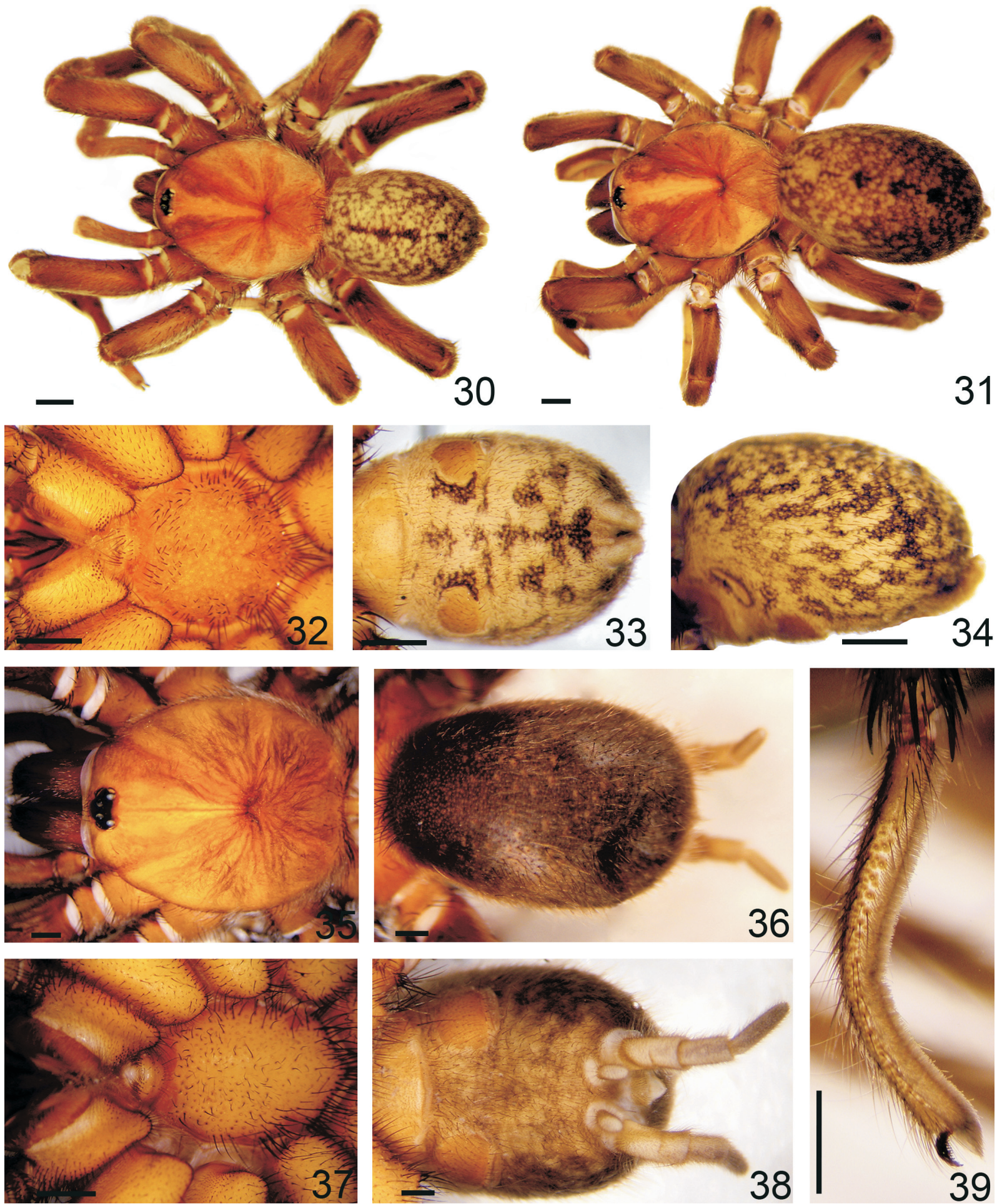

Figures 30-39. Acanthogonatus ericae sp. nov. and Xenonemesia araucaria sp. nov. (30-34) Xenonemesia araucaria sp. nov.; (30) male body, dorsal view; (31) female body, dorsal view; (32-34) male; (32) sternum, ventral view; (33-34) abdomen; (33) ventral view; (34) lateral view; (35-39) Acanthogonatus ericae sp. nov.; (35-39) male; (35) carapace, dorsal view; (36) abdomen, dorsal view; (37) sternum, ventral view; (38) abdomen, ventral view; (39) tarsus IV, prolateral view. Scale bars $=1 \mathrm{~mm}$. Photos. R.P. Indicatti.

Revista Brasileira de Zoologia 25 (3): 529-546, September, 2008 

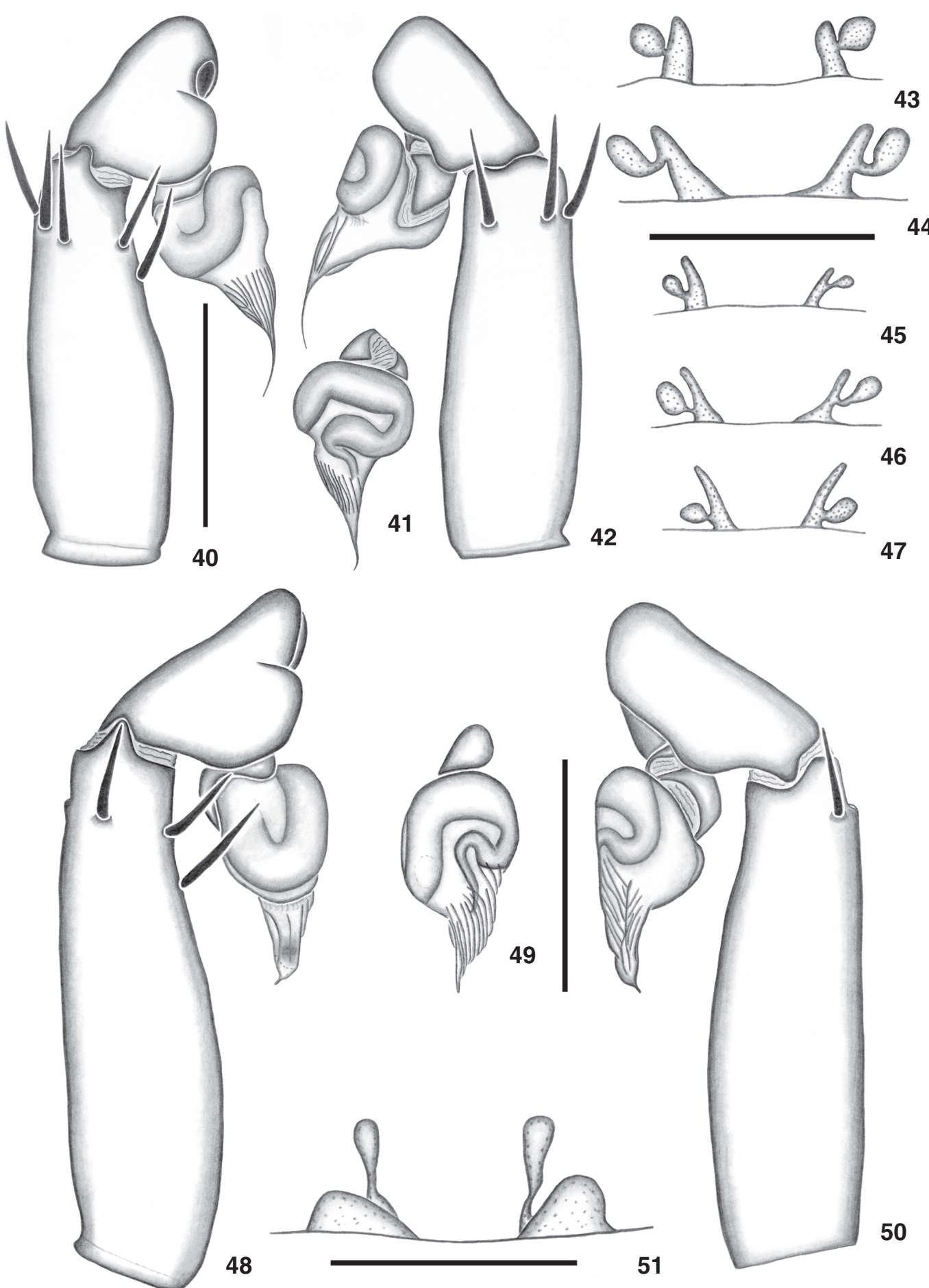

Figures 40-51. Stenoterommata palmar and S. arnolisei sp. nov. (40-47) Stenoterommata palmar; (40-42) male, left palpal bulb; (40) prolateral view; (41) ventral view; (42) retrolateral view; (43-47) female, spermathecae variation, dorsal view; (43) IBSP 12720; (44) MCTP 14419; (45) IBSP 12723; (46) MCTP 16743; (47) IBSP 12724; (48-51) Stenoterommata arnolisei sp. nov.; (48-50) male, left palpal bulb; (48) prolateral view; (49) ventral view; (50) retrolateral view; (51) female, spermathecae, dorsal view. Scale bars $(40-42,48-50)=$ $1 \mathrm{~mm} ;(43-47,51)=0,5 \mathrm{~mm}$. 
Female (paratype MCN 42909). Coloration as in male. Total length 15.0. Carapace 5.8 long, 4.8 wide, short and procurved fovea. Clypeus narrow 0,28. Eyes as in male. Basal segment of chelicerae with 12-13 teeth in one row on the prolateral margin and rastellum with very strong setae. Intercheliceral tumescence absent. Labium 0.4 long, 1.0 wide, with one cuspule. Endites with 96-105 cuspules. Serrula absent. Sternum oval 2.8 long, 2.5 wide. Six sternal sigilla marginal, posterior twice the size of anterior. Palp: measurements: femur 2.8/ patella 2.8 /tibia $1.7 /$ cymbium $1.7 /$ total 9.0 ; spination: femur d1-1-1-1p, tibia v1r-2-0, p1p. Legs: measurements: I: femur 4.0/ patella $2.2 /$ tibia $2.7 /$ metatarsus $2.3 /$ tarsus $1.6 /$ total 12.8 ; II: $3.6 /$ 2.4/2.5/2.2/1.6/12.3; III: 3.4/2.1/2.1/2.7/1.5/11.8; IV: 4.4/2.6/ 3.1/4.1/1.8/16.0; spination: I: femur d1-1-1-1p, tibia megaspine absent, metatarsus v1r-1r-1r; II: femur d1-1-1-1p, tibia v1r, metatarsus v2-2-2; III: femur d1-1-3, patella d1p-2-1p, p1-1, r1, tibia d1, v2-1r-2, p1-1, r1, metatarsus d2-2-2, v2-2-2, p1-1-1, r1-1-1; IV: femur d1-1-1, tibia v2-2-2, p1-1, r1-1, metatarsus d1-2-2, v2-2-2, p1, r1-1-1. Preening combs on metatarsi II: 4VP, III: 5VP, 5VR and IV: 3VP, 5VR. Tarsi IV flexible. Scopula present on tarsi I-II and on tarsi II divided by few rows of thin setae. Superior tarsal claws large with a double row of 5-6 teeth on tarsi I and II, 5-7 on tarsi III, 6-7 on IV. Third claw present on all tarsi. Four spinnerets, PLS three segmented, basal segment 1.1 , median segment 0.8 , apical segment triangular 0.6 long. Female genitalia with a rounded base separated by their length (Fig. 51).

Variation. Males $(\mathrm{n}=20)$ : total length 10.0-12.8; carapace 5.2-6.6; femur I: 4.1-4.5; endites with 72-80 cuspules. Females: total length 14.0-15.8; carapace 5.8-6.8; femur I: 3.94.4; endites with 94-108 cuspules.

Additional material examined. BrazIL. Rio Grande do Sul: São Francisco de Paula (Potreiro Velho, Centro de Pesquisa e Conservação da Natureza Pró-Mata), R. Ott leg., 2 males, 01.V.2001 (IBSP 113621); 1 female, 02.II.2002 (IBSP 113622); 1 male, 14.IV.2002 (IBSP 113623); 1 male, 07.VII.2001 (IBSP 113624); 108 males and 14 females, 25.X.2000-18.V.2002 (MCTP); (Potreiro Velho), 2 males, 30.IV-06.V.1997, J. Ketterl leg. (MCTP 17502; IBSP 113633).

Natural history. As in the case of $S$. palmar, two males were collected in trunks of Araucaria angustifolia trees in the CPCN Pró-Mata, with upwards arboreal photoecletors of trunks (for more details see BREsCovit et al. 2004).

Distribution. Known from South of Brazil, state of Rio Grande do Sul.

\section{Stenoterommata grimpa sp. nov. Figs $52-55$}

Types. Male holotype and female paratype, BrazIL, Rio Grande do Sul: São Francisco de Paula, (Potreiro Velho, Centro de Pesquisa e Conservação da Natureza Pró-Mata), 07.VII.2001, R. Ott leg., deposited in MCN 42905 and MCN 42906, respectively; Paratype male, BraziL, Rio Grande do Sul: São Francisco de Paula, Potreiro Velho, IX.2001, L.A. Bertoncello \& A.A. Lise leg. (MCTP 19411).

Etymology. The specific name is a noun in apposition that refers to the popular name of the dry branch of Araucaria which is very spiny and used to start fires in this region of Rio Grande do Sul.

Diagnosis. The males of Stenoterommata grimpa sp. nov. resemble those of $S$. arnolisei sp. nov. (Figs 27 and 48-50) by the shape of the palpal bulb and by the short embolus, but differ by the keels, restricted to the apical region (Figs 52-54). The female differs from remaining Stenoterommata by the presence of two spermathecae in the rounded fused basal dome (Fig. 55).

Description. Male (holotype). Coloration pattern: carapace yellowish brown, legs brown. Abdomen dorsally brown with symmetrical yellow stains and ventrally pale yellow, with posterior darker stains. Total length 8.2. Carapace 4.5 long, 3.3 wide, with a short and procurved fovea. Clypeus narrow 0.28. Anterior eyes row procurved, posterior slightly recurved. AME smaller than ALE, ALE larger than PLE and PME smaller than PLE. Overall shape of eye group trapezoidal, wider than long in ratio. Basal segment of chelicerae with eight teeth in a row on the prolateral margin and rastellum with very strong setae. Intercheliceral tumescence small, pale covered by few hairs. Labium 0.4 long, 0.6 wide, without cuspules. Endites with 70/ 73 cuspules. Serrula present. Sternum oval 2.2 long, 1.7 wide. Six sternal sigilla marginal, posterior twice the size of anterior. Palp: measurements: femur 2.1/patella 1.2/tibia 1.6/cymbium 0.6/total 5.5; spination: femur d1-1-1-1-3-3, tibia d2, v2p. Legs: measurements: I: femur 3.1/patella 2.1/tibia 2.3/metatarsus 2.2 / tarsus 1.5/total 10.2; II: 2.9/1.9/1.9/2.1/1.5/10.3; III: 2.8/1.7/ 1.5/2.2/1.3/9.5; IV: 3.6/2.0/2.5/3.5/1.5/13.1; spination: I: femur d1-1-1-2, tibia v1r-2r-1p, p1-1-1, megaspine present, metatarsus v2-2-2; II: femur d1-1-1-2, tibia v1r-1r-2, p1-1, metatarsus v2-2-2, p1-1; III: femur d1-1-2-2, patella p1-1-1, r1, tibia d1, v2-2-2, p1-1-1, r1-1-1, metatarsus d2-2-2, v2-2-2, p1-1-1, r1-11; IV: femur d1-1-1-2, patella r1, tibia v2-2-2, p1-1, r1-1, metatarsus d2-2-2, v2-1p-2-2, p1-1-1, r1-1-1. Metatarsal preening combs on legs III: 4VP, 4VR and IV: 3VP, 3VR. Tarsi III-IV flexible. Scopula present on all tarsi and half of metatarsi I-II. Superior tarsal claws large with a double row of 6-7 teeth on tarsi I, 7 on tarsi II-IV. Third claw present on all tarsi. Four spinnerets, PLS three segmented, basal segment 0.5 , median segment 0.4 , apical segment triangular 0.5 long. Palpal bulb piriform with a very short embolus (Figs 52-54).

Female (paratype MCN 42906). Coloration as in male. Total length 18.2. Carapace 7.2 long, 6.0 wide, short and procurved fovea. Clypeus narrow 0.32. Eyes as in male. Basal segment of chelicerae with 13 teeth in a row on the prolateral margin and rastellum with very strong setae. Intercheliceral tumescence absent. Labium 0.6 long, 1.2 wide, with one cuspule. Endites with 80/85 cuspules. Serrula absent. Sternum oval 3.4 long, 3.5 wide. Six sternal sigilla marginal, posterior 


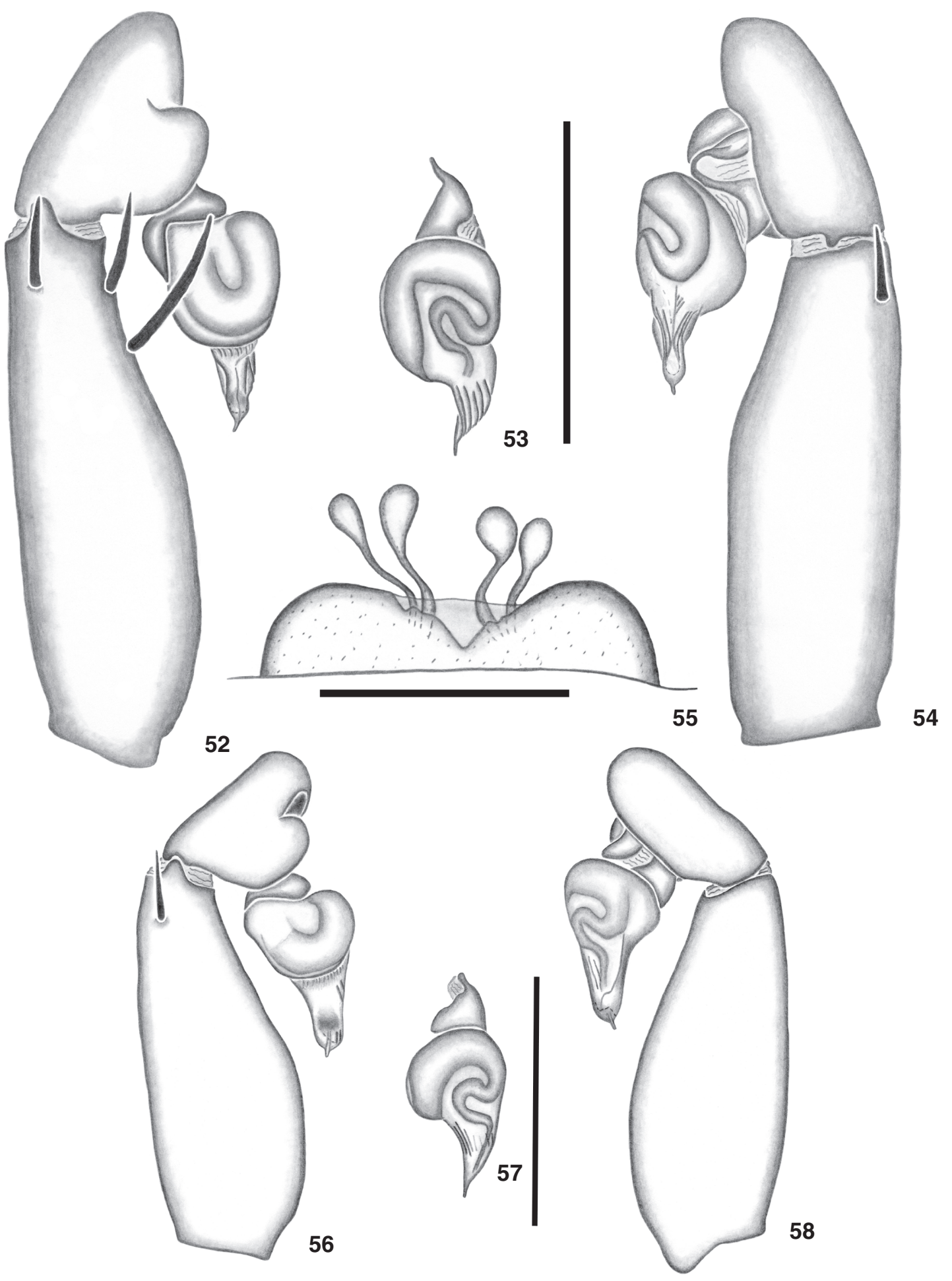

Figures 52-58. Stenoterommata grimpa sp. nov. and S. curiy sp. nov. (52-55) Stenoterommata grimpa sp. nov.; (52-54) male, left palpal bulb; (52) prolateral view; (53) retrolateral view; (54) ventral view; (55) spermathecae, dorsal view; (56-58) Stenoterommata curiy sp. nov.; (56-58) male, left palpal bulb; (56) prolateral view; (57) ventral, view; (58) retrolateral view. Scale bars $(52-54,56-58)=1 \mathrm{~mm}$; $(55)=0,5 \mathrm{~mm}$. 
twice the size of anterior. Palp: measurements: femur 3.6/patella 2.1/tibia 2.2/cymbium 2.2/total 10.1; spination: femur d11-1-1-2, patella v3, tibia v2-2-2, p2-1. Legs: measurements: I: femur 4.8 /patella $3.4 /$ tibia $3.6 /$ metatarsus $3.1 /$ tarsus $2.1 /$ total 17.0; II: 4.4/3.4/2.4/3.0/2.0/16.2; III: 4.1/2.4/2.4/3.8/1.8/14.5; IV: 5.7/3.0/3.8/5.3/2.1/19.9; spination: I: femur d1-1-1-1-1, metatarsus v2-1p-1p; II: femur d1-1-1-1-1, tibia v1m-1m, metatarsus v2-2-2; III: femur d1-1-1-1-1, tibia d2-2-2, v2-2-2, p1-1, r1, metatarsus d1-2-2-2, v2-2-2, p1-1-1, r1-1-1; IV: femur d1-11-1-1, patella p2, tibia v1r-2-2, p1-1, r1-1, metatarsus d2-1p-22, v2-2-1p-2, p1-1-1, r1-1-1. Preening combs on metatarsi II: 5VP, III: 7VP, 5VR and IV: 4VP, 5VR. Tarsi IV flexible. Scopula present on tarsi I-II, scopula of tarsi II divided by few rows of thin setae and in the metatarsi II only on the sides. Superior tarsal claws large with a double row of 5-7 teeth on tarsi I, 6-7 on II, 6-8 on tarsi III-IV. Third claw present on all tarsi. Four spinnerets, PLS three segmented, basal segment 1.1, median segment 1.0, apical segment triangular 0.8 long.

Additional material examined. None.

Distribution. Known from southern Brazil, state of Rio Grande do Sul.

\section{Stenoterommata curiy sp. nov. Figs $56-58$}

Types. Male holotype, BraziL, Rio Grande do Sul: São Francisco de Paula, (Potreiro Velho, Centro de Pesquisa e Conservação da Natureza Pró-Mata), 25.X.2000, R. Ott leg., deposited in MCN 42913; paratypes: 3 males, 07.VII-09.VIII.2001 (MCN 42914; IBSP 113562; MCTP 20469); (Floresta Nacional de São Francisco de Paula), 3 males, VIII.2003, F. Joner leg., (MCN 42915; MCTP 20470; IBSP 113563).

Etymology. The specific name is a noun in apposition taken from the Guarani indian language that refers to Araucaria trees (Pinheiro-do-Paraná or Pinheiro-Brasileiro).

Diagnosis. The males of Stenoterommata curiy sp. nov. resemble those of $S$. grimpa sp. nov. (Figs 52-54) by the shape of palpal bulb and the very short embolus, but differ by the translucid keels restricted to the larger distal region (Figs 56-58).

Description. Male (holotype). Coloration pattern: carapace yellowish brown, legs brown. Abdomen dorsally with symmetrical yellowish brown stains and ventrally yellowish, with posterior darker stains. Total length 8.6. Carapace 4.2 long, 3.3 wide, short and procurved fovea. Clypeus narrow 0,22. Anterior eye row procurved, posterior slightly recurved. AME smaller than ALE, ALE larger than PLE and PME smaller than PLE. Overall shape of eye group trapezoidal, wider than long in ratio. Basal segment of chelicerae with 11 teeth in a row on the prolateral margin and rastellum with very strong setae. Intercheliceral tumescence small, pale covered by few hairs. Labium 0.4 long, 0.6 wide, without cuspules. Endites with 75/ 77 cuspules. Serrula present. Sternum oval 2.0 long, 1.80 wide. Six sternal sigilla marginal, posterior twice the size of anterior. Palp: measurements: femur 2.1/patella 1.2/tibia 1.40/cymbium 0.6/total 5.3; spination: femur d1-1-1-2, tibia p1, r2. Legs: measurements: I: femur 2.9/patella 1.8/tibia 2.0/metatarsus 2.0/tarsus $1.2 /$ total 9.9; II: 2.6/1.7/1.8/1.8/1.2/9.1; III: 2.5/1.3/1.3/2.2/ 1.2/8.5; IV: 3.3/1.5/1.7/2.6/1.0/10.1; spination: I: femur d1-11-1-1, tibia v1-2, p1-1, retrolateral megaspine present, metatarsus v2-1, p1-1; II: femur d1-1-1-1-1, tibia v1-1-2, p1-1, metatarsus v1-1-2, p1-1; III: femur d1-3-3-3, patella p2, r1, tibia d1, v2-2, p1-1, r1-1, metatarsus d2-2-2, v2-2-3, p1-1-1, r1-1-1; IV: femur d1-1-2-3, patella r1, tibia v2-2, p1-1, r1-1, metatarsus d1-2-1, v2-2-3, p1-1-1, r1-1-1. Metatarsal preening combs on ventral legs III: $4 p$, $4 r$ and IV: 5p, 3r. Tarsi I-IV flexible. Scopulae present on tarsi and half of metatarsi I-II. Superior tarsal claws large with a double row of 6 teeth on tarsi I, 6-7 on tarsi II, 8-10 on tarsi III, 7-9 on tarsi IV. Third claw present on all tarsi. Four spinnerets, PLS three segmented, basal segment 0.7, median segment 0.4, apical segment triangular 0.4 long. Palpal bulb piriform with a very short embolus (Figs 56-58).

Female. Unknown.

Variation. Males $(n=15)$ : total length 7.3-8.9; carapace 3.7-4.5; femur I: 3.5-4.4.

Additional material examined. Brazil. Rio Grande do Sul: São Francisco de Paula (Potreiro Velho, Centro de Pesquisa e Conservação da Natureza Pró-Mata), 1 male, 14.IX.2002 (IBSP 113614); (Floresta Nacional de São Francisco de Paula), 10 males, VIII.2003, F. Joner leg. (MCN 42916-42920; IBSP 113564; 113565; MCTP 20471; 20472).

Distribution. Known from southern Brazil, state of Rio Grande do Sul.

\section{Ecological data}

A total of 9461 spiders (8940 Araneomorphae and 521 Mygalomorphae) were collected over the course of 20 months of pitfall trapping at the CPCN-Pró-Mata. From the herein described species of Microstigmatidae and Nemesiidae, a total of 238 specimens were collected. Two species were recorded in large numbers allowing some ecological inference on their phenology and habitat preferences: Xenonemesia araucaria sp. nov. and Stenoterommata arnolisei sp. nov.

Stenoterommata arnolisei sp. nov. was the most abundant Nemesiidae species, with a total of 142 collected specimens. The phenology graph for this species (Fig. 59) shows that the highest activity periods for males were recorded from the beginning of fall to the end of spring; this period is probably coincident with the reproductive period of this species. Females were less abundant and did not show any clear activity peaks; however the highest female abundance at traps was recorded in spring and summer. The abundance of this species among the different sampled areas did not show a clear preference pattern between studied habitat types (Fig. 60). Peréz-Miles et al. (1993) also recorded an unknown Stenoterommata species as the most abundant mygalomorph spider collected with pitfall traps at Uruguay; in this case males showed an uneven seasonal distribution, with peaks in fall and spring. For $S$. arnolisei sp. nov., no habitat preference was detected and the present 



Figures 59-60. Stenoterommata arnolisei sp. nov. (59) Phenology, based on the specimens activity (individuals/day); (60) Average number (points) and standard deviation (bars) relative to the individuals number collected. Data of the six sampled areas, of three different forest habitats (ARA, araucaria forests Araucaria; SEC, secondary forests; PIN, pine silvicultures); (59-60) Individuals collected with pitfall traps, in CPCN Pró-Mata, São Francisco de Paula, Rio Grande do Sul, between 22. IX.2000 and 18.V.2002.

data suggest that Stenoterommata species are tolerant to different habitat conditions. The reproductive peaks of this species, with an overwintering activity pattern, are very similar to other small-sized mygalomorph spiders (Peréz-Miles et al. 1993; Costa \& Pérez-Miles 2002).

Xenonemesia araucaria sp. nov. was the only Microstigmatidae present in the studied areas. A total of 69 specimens was collected during the entire sampling period. Males were clearly most active during spring and summer; females showed a slight increase in activity from the end of summer through the fall (Fig. 61). The phenological pattern of this species was quite different from that of other small size mygalomorphs (PerézMiles et al. 1993; Costa \& Pérez-Miles 2002) and from S. arnolisei sp. nov. The abundance of this species, throughout the different sampled areas, as for $S$. arnolisei sp. nov., does not show any preference between the studied habitat types; however, the highest catch numbers of this species were recorded at both disturbed Araucaria forests and lower catch numbers were recorded at both Pines silvicultures (Fig. 62). Goloboff (1988) described many habitats (river banks, xerophilous and disturbed environments) for where specimens of $X$. platensis were collected, but no conclusive data about any habitat preference were presented for this species. Species of Xenonemesia seem to be tolerant to disturbed environments, as are the Stenoterommata species (Nemesiidae) species discussed here.
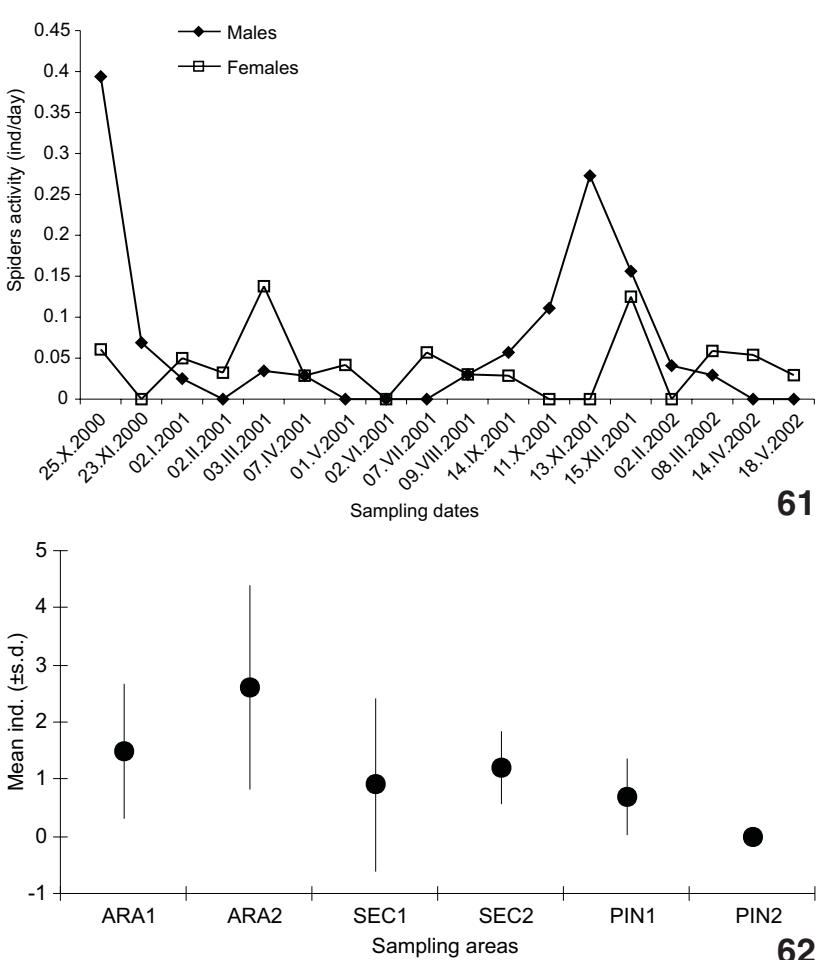

Figures 61-62. Xenonemesia araucaria sp. nov. (61) Phenology, based on the specimens activity (individuals/day); (62) Average number (points) and standard deviation (bars) relative to the individuals number collected. Data of the six sampled areas, of three different forest habitats (ARA, Araucaria forest; SEC, secondary forest; PIN, Pine forestation); (61-62) Individuals collected with pitfall traps, in CPCN Pró-Mata, São Francisco de Paula, Rio Grande do Sul, between 22. IX.2000 and 18.V.2002.

The other recorded species show reduced catch numbers: Acanthognatus ericae sp. nov. (seven specimens), Stenoterommata curiy sp. nov. (five), S. grimpa sp. nov. (two) and S. palmar (13) (Tab. II). No relations between the studied habitat types were evidenced due to the low catch numbers of these species. However, all seven specimens of $A$. ericae sp. nov. were collected exclusively in one area of secondary forest (Tab. II). We were not able to come to a conclusive explanation for the restricted distribution of this species, although the referred area (SEC2) is at the most eastern position, near slopes with predominance of Atlantic Forest areas (Dense Ombrophilous Forest). This species could probably be non typical for the majority of the Araucaria Forest areas. 
Table II. Record of the number of individuals of the less-abundant species of Acanthogonatus and Stenoterommata (Nemesiidae), collected in the six sampled areas, of three different forest habitats, in CPCN Pró-Mata, São Francisco de Paula, Rio Grande do Sul, between 22.IX.2000 and 18.V.2002. (ARA) Araucaria forest, (SEC) secondary forest, (PIN) Pine forestation.

\begin{tabular}{|c|c|c|c|c|c|c|c|}
\hline Species & ARA1 & ARA2 & SEC1 & SEC2 & PIN1 & PIN2 & $S$ \\
\hline Acanthogonatus ericae sp. nov & & & & 7 & & & 7 \\
\hline Stenoterommata curiy sp. nov. & & 1 & & 3 & & 1 & 5 \\
\hline Stenoterommata grimpa sp. nov. & & 1 & & 1 & & & 2 \\
\hline Stenoterommata palmar & 1 & 3 & 4 & & 2 & 3 & 13 \\
\hline$\Sigma$ & 1 & 5 & 4 & 11 & 2 & 4 & 27 \\
\hline
\end{tabular}

The seasonal catch data of the above mentioned less abundant species are presented on table I. For all referred species males do not were registered along the summer months. This sazonal pattern is very similar to the pattern presented by S. arnolisei sp. nov. and other small mygalomorphs (PerÉz-Miles et al. 1993; Costa \& Pérez-Miles 2002).

\section{ACKNOWLEDGMENTS}

We thank Cristina A. Rheims (Instituto Butantan), Walter A. P. Boeger (Universidade Federal do Paraná, Curitiba) and an anonymous reviewer for helpful comments on this manuscript; Erica H. Buckup and Arno A. Lise for loaning the specimens from southern Brazil included in this paper and donating duplicates to IBSP; Cristina L. Scioscia by the permission of the examination of the type specimens of $S$. palmar in collection of Museo Argentino de Ciencias Naturales "Bernardino Rivadavia", Buenos Aires; Pedro Kiyohara and Simone P. de Toledo, from the Laboratório de Microscopia Eletrônica do Instituto de Física, Universidade de São Paulo, São Paulo, for making the scanning electron micrographs and Cláudio M. Fett Filho by the helpful modification on color plate. This study was supported by Fundação de Amparo à Pesquisa do Estado de São Paulo (FAPESP 99/054468), Coordenação de Aperfeiçoamento de Pessoal de Ensino Superior (RPI and RO) and Conselho Nacional de Pesquisa (141062/ 2007-0, RPI and 301776/2004-0, ADB). This paper was developed in the Programa de Pós-Graduação em Biologia Animal da Universidade Federal Rural do Rio de Janeiro. This work is part of the BIOTA/FAPESP - The Biodiversity Virtual Institute Program (www.biotasp.org.br).

\section{LITERATURE CITED}

Bertoletti, J.J. \& M.B. Teixeira. 1997. Centro de Pesquisas e Conservação da Natureza Pró-Mata: Plano de Trabalho para a Elaboração do Plano de Manejo. Divulgações do Museu de Ciências e Tecnologia-UBEA/PUCRS 3: 3-27.

Brescovit, A.D.; L.A. Bertoncello; R. Ott \& A.A. Lise. 2004. Description and ecology of two new species of the Brazilian spider genus Losdolobus Platnick \& Brescovit (Araneae, Dysderoidea, Orsolobidae). Revista Ibérica de Aracnologia 9: 249-257.
BüCherl, W. 1952. Aranhas do Rio Grande do Sul. Memórias do Instituto Butantan 24: 127-155.

Costa, F. G \& F. Pérez-Miles. 2002. Reproductive biology of uruguayan teraphosids (Araneae, Mygalomorphae). Journal of Arachnology 30: 571-587.

Goloboff, P.A. 1988. Xenonemesia, un nuevo genero de Nemesiidae (Araneae, Mygalomorphae). Journal of Arachnology 16: 357-363.

GoLoвоF, P.A. 1993. A reanalysis of mygalomorph spiders families (Araneae). American Museum Novitates 3056: 1-32.

Goloboff, P.A. 1995. A revision of the South American spiders of the family Nemesiidae (Araneae, Mygalomorphae). Part I: species from Peru, Chile, Argentina, and Uruguay. Bulletin of the American Museum of Natural History 224: 1-189.

Guadanucci, J.P.L. \& R.P. Indicatti. 2004. Redescription of Fufius funebris Vellard, 1924 and description of Fufius lucasae sp. nov. with comments on Ctenochelus maculatus Mello-Leitão, 1923 (Mygalomorphae, Cyrtaucheniidae). Revista Ibérica de Aracnologia 10: 256-260.

Holmberg, E.L. 1881. Géneros y especies de arácnidos argentinos nuevos ó poco conocidos. Anales de la Sociedad Científica Argentina 11: 125-133, 169-177, 270-278.

Indicatti, R.P.; S.M. LuCAS \& A.D. Brescovit. 2007. A new species of the spider genus Xenonemesia Goloboff from Brazil, with comments on X. platensis Goloboff (Araneae, Mygalomorphae, Microstigmatidae). Zootaxa 1485: 43-49.

Indicatti, R.P.; S.M. Lucas; J.P.L. Guadanucci \& F.U. Yamamoto. 2008. Revalidation and revision of the genus Magulla Simon, 1892 (Araneae, Mygalomorphae, Theraphosidae). Zootaxa 1814: 21-36.

KarsCH, F. 1880. Arachnologische Blätter (Decas I). Zeitschrift für die gesammten Naturwissenschaften 53: 373-409.

Lucas, S.M. \& R.P. IndicatTi. 2006. On the genus Psalistopoides Mello-Leitão (Araneae, Mygalomorphae, Nemesiidae). Revista Brasileira de Zoologia 23: 547-549.

Lucas, S. M.; R.P. Indicatti; A.D. Brescovit \& R. C. Francisco. 2006. First record of the Mecicobothriidae Holmberg from Brazil, with a description of a new species of Mecicobothrium (Araneae, Mygalomorphae). Zootaxa 1326: 45-53.

Mello-Leitão, C. F. de. 1943. Catálogo das aranhas do Rio Grande do Sul. Archivos do Museu Nacional do Rio de Janeiro 
37: 147-245.

Petrunkevitch, A. 1925. Arachnida from Panamá. Transactions of the Connecticut Academy of Arts and Sciences 27: 51-248. Pérez-Miles, F.; F.G. Costa \& E. Gudynas. 1993. Ecologia de uma comunidad de Mygalomorphae criptozoicas de sierra de las animas, Uruguay (Arachnida, Araneae). Aracnologia 17/18: $1-22$.

Submitted: 30.VIII.2007; Accepted: 10.IX.2008.

Editorial responsibility: Georgina Bond-Buckup
Platnick, N.I. 2008. The world spider catalog, version 9.0. American Museum of Natural History, available online at http://research.amnh.org/entomology/spiders/catalog/ index.html [Accessed in 15.VII.2008].

RAVEN, R.J. 1985. The spider infraorder Mygalomorphae (Araneae): Cladistics and systematics. Bulletin of the American Museum of Natural History 182: 1-180. 